\title{
REVITALISASI PEMBANGKIT LISTRIK TENAGA SURYA (PLTS) PADA SISTEM MICROGRID PULAU TOMIA
}

\author{
Putu Agus Aditya Pramana ${ }^{1)}$, Brian Bramantyo S. D. A. Harsono ${ }^{2}$, Kevin Gausultan Hadith \\ Mangunkusumo ${ }^{3}$ ) \\ ${ }^{1,2,3)}$ Bidang Transmisi dan Distribusi, PT PLN (Persero) Puslitbang (Research Institute) \\ Email: putu.pramana@pln.co.id ${ }^{1)}$ \\ Asal Negara: Indonesia
}

\begin{abstract}
ABSTRAK
Pulau Tomia merupakan salah satu pulau di Kabupaten Wakatobi, Provinsi Sulawesi Tenggara yang menggunakan konsep microgrid untuk mengaliri listrik masyarakatnya. Konsep microgrid tersebut mengintegrasikan Pembangkit Listrik Tenaga Diesel (PLTD) dan Pembangkit Listrik Tenaga Surya (PLTS). Namun, saat ini kondisi sistem PLTS di Pulau Tomia tidak dapat memproduksi listrik karena terjadi permasalahan dan berdampak pada potensi energy not served (ENS) serta kerugian investasi dalam pembangunan sistem microgrid. Dalam makalah ini dijelaskan proses revitalisasi pada sistem PLTS di Pulau Tomia dengan harapan makalah ini dapat menjadi referensi pada proses revitalisasi PLTS di lokasi lainnya. Proses revitalisasi pada PLTS Tomia dilaksanakan melalui beberapa tahapan, yaitu: review desain eksisting PLTS Tomia, investigasi penyebab gangguan, inisiatif perbaikan, dan desain ulang PLTS Tomia. Berdasarkan hasil investigasi gangguan dapat diketahui bahwa penyebab tidak beroperasinya PLTS Tomia adalah gangguan pada rangkaian PLTS, Grid Tied Inverter (GTI), dan elemen penyimpan (baterai). Berdasarkan hasil analisis lebih lanjut, didapatkan inisiatif perbaikan yang dapat ditindaklanjuti dengan hasil terbaik dan cara yang termudah, yaitu dengan melakukan desain ulang pada rangkaian combiner box PLTS dan mengimplementasikan konsep GTI modular. Hal tersebut dilakukan agar keandalan PLTS tetap terjaga jika salah satu GTI mengalami permasalahan. Hasil revitalisasi menunjukkan bahwa nilai kualitas daya berupa harmonisa tegangan dan arus yang dihasilkan oleh GTI telah memenuhi standar. Selain itu, PLTS Tomia hasil revitalisasi mampu menghasilkan potensi penghematan Biaya Pokok Produksi (BPP) Listrik yang semula adalah sebesar Rp. 3080/kWh menjadi Rp. 2983/kWh.
\end{abstract}

Kata kunci: Microgrid, PLTS, PLTD, inverter, BPP

ABSTRACT

Tomia Island is one of the islands in Wakatobi Regency, Southeast Sulawesi Province which uses the microgrid concept to provide electricity to its people. The microgrid concept integrates Diesel Power Plant and Solar Power Plant/Photovoltaic (PV) System. However, the existing PV system on Tomia Island cannot produce electricity due to problems that has an impact on the energy not served (ENS) as well as an ineffective investment of the microgrid system. For this reason, this paper describes the revitalization process in the PV system in Tomia Island with the hope that this paper can be used for the revitalization process of $P V$ microgrids in other locations. The revitalization process of the $P V$ system is carried out in several stages, namely reviewing the existing $P V$ design, investigating the causes of disturbances, repair initiatives, and redesigning the PV. From the results of the investigation, the causes of the PV problem in Tomia are the disturbance in the PV array, Grid Tied Inverter (GTI), and storage elements (batteries). Based on the results of further analysis, there are improvement initiatives that can be followed up with the best results and the easiest way, namely redesigning the PV combiner box and implementing the modular GTI concept. It was performed to maintain the reliability of the PV if one of the GTIs has problems. The results of the revitalization show that the power quality (in the form of voltage and current harmonics generated by GTI) has met the standards as well as the revitalization potentially saved the Electricity Cost of Production (BPP), which was originally Rp. 3080 / kWh to Rp. 2983 / kWh.

\section{Keywords: microgrid, PV, Diesel Power Plant, inverter, electricity cost of Production.}

\section{PENDAHULUAN}

Indonesia memiliki banyak pulau yang sistem kelistrikannya dibangkitkan secara lokal. Saat ini, kebutuhan energi listrik daerah kepulauan sebagian besar disuplai dengan menggunakan pembangkit listrik tenaga diesel (PLTD) serta pembangkit energi terbarukan seperti tenaga surya (PLTS). Konfigurasi antara PLTS dan PLTD tersebut umumnya disebut sebagai microgrid. Microgrid sendiri dapat dijelaskan sebagai suatu sistem kelistrikan yang terintegrasi pada wilayah kecil dengan sumbersumber pembangkit terdistribusi (Member et al., 2016).

Saat ini terdapat puluhan instalasi microgrid yang tersebar di Indonesia, salah satunya seperti yang terdapat di pulau Tomia. Pulau Tomia merupakan 
salah satu pulau di Kabupaten Wakatobi, Sulawesi Tenggara. Pulau Tomia menggunakan konsep microgrid yang mengintegrasikan PLTD dengan PLTS. Sebelum digunakannya konsep microgrid, suplai untuk Pulau Tomia dilakukan dengan menggunakan PLTD sehingga BPP menjadi tinggi. Penerapan konsep microgrid ini diharapkan mampu mengurangi nilai BPP mengingat Pulau Tomia memiliki potensi energi surya yang cukup besar. Seiring dengan usia pengoperasiannya, kondisi sistem PLTS di Pulau Tomia tidak dapat beroperasi karena terjadi gangguan sehingga menyebabkan terjadinya potensi energy not served (ENS) sebesar $122.000 \mathrm{kWh}$ per tahun serta kerugian investasi dalam pembangunan sistem microgrid.

Terdapat beberapa peneliti yang sudah membahas sistem microgrid, dimulai dari pemanfaatan baterai sebagai penyimpan energi (Mckeon et al., 2013; Serban et al., 2013), fungsi baterai sebagai penyangga frekuensi maupun tegangan jika terjadi perubahan yang signifikan pada pembangkit dan beban (Bae et al., 2012; Xia et al., 2019), pembahasan sistem kontrol pengaturan daya pada inverter (Che et al., 2015; Jiang et al., 2007; Patarroyo-montenegro et al., 2017; Wang et al., 2011; Zhao et al., 2015; Liu et al., 2019), serta manajemen energinya (Dong et al., 2020; Jos et al., 2020). Namun, belum ditemukan artikel yang membahas mengenai proses revitalisasi suatu aset microgrid yang sedang mengalami permasalahan.

Melihat besarnya potensi losses dari suatu microgrid yang tidak dapat beroperasi serta kurangnya referensi yang menjelaskan proses revitalisasi PLTS, maka dalam makalah ini dibahas proses investigasi gangguan dan revitalisasi PLTS Tomia. Diharapkan kedepannya makalah ini dapat digunakan sebagai salah satu referensi/kerangka kerja untuk perbaikan jika terdapat kerusakan pada sistem microgrid di lokasi yang lain.

\section{METODE}

Dalam melaksanakan revitalisasi PLTS Tomia dilakukan beberapa tahapan analisis gangguan dimulai dari review desain eksisting PLTS Tomia, investigasi penyebab gangguan, inisiatif perbaikan, dan desain ulang PLTS Tomia.

\subsection{Review Desain Eksisting PLTS Tomia}

PLTS Tomia merupakan PLTS tipe grid-tied yang memiliki kapasitas sebesar $75 \mathrm{kWp}$. Adapun diagram blok sistem PLTS Tomia diberikan pada Gambar 1. yang menunjukkan bahwa sistem tersebut terdiri dari panel surya (PLTS), Grid Tied Inverter (GTI), low pass filter (LPF), trafo GTI, baterai, dan sistem charger (bidirectional inverter). Sinkronisasi PLTS Tomia dengan grid PLN dilakukan pada busbar $380 \mathrm{~V}$. Setelah sinkron, tegangan kemudian dinaikkan menjadi $20 \mathrm{kV}$ menggunakan trafo step up.

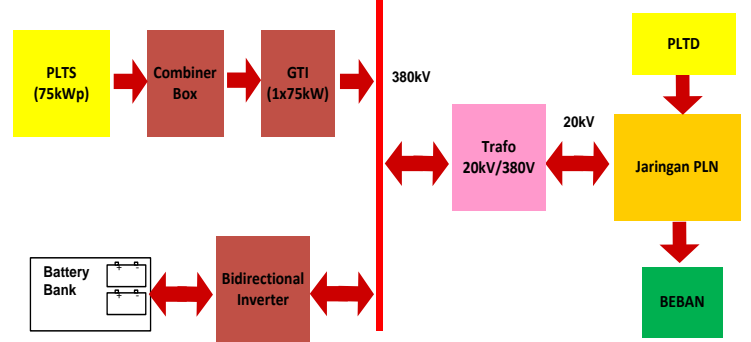

Gambar 1. Diagram eksisting PLTS Tomia pada sistem microgrid

Panel surya yang digunakan pada PLTS Tomia berdaya $75 \mathrm{kWp}$ yang terdiri dari satu array dengan nilai tegangan DC sebesar $640 \mathrm{Vdc}$, seperti diberikan pada Gambar 2.

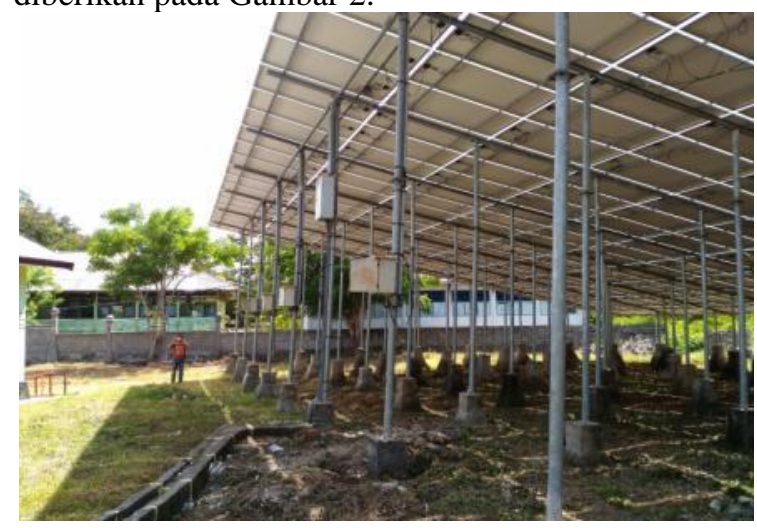

Gambar 2. Array dari modul PLTS Tomia

Array PLTS tersebut dihubungkan melalui sebuah combiner box. Pada saat survei di lapangan, panel combiner box tersebut sudah tidak dapat digunakan karena konduktor penghubung dari combiner box ke control room terbakar dan putus, seperti diperlihatkan pada Gambar 3.

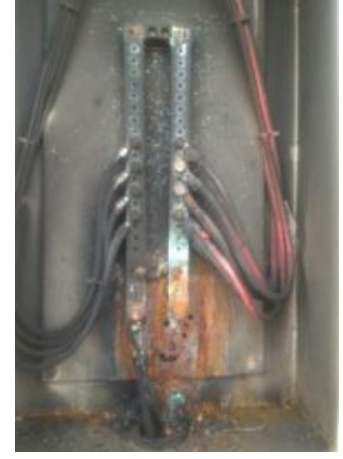

Gambar 3. Combiner box eksisting PLTS Tomia

GTI eksisting yang digunakan pada PLTS Tomia merupakan satu GTI tiga fasa dengan kapasitas 1x75 kWp. Proses pensaklaran pada inverter menggunakan saklar insulated gate bipolar transistor (IGBT) yang dikontrol oleh maximum power point tracker (MPPT) dengan metode pulse width modulation (PWM). Penggunaan GTI pada sistem PLTS Tomia menghasilkan tegangan dan arus AC output dengan bentuk gelombang yang tidak sinusoidal murni, dimana masih mengandung komponen harmonisa. Pada metode penyaklaran 
PWM, komponen harmonisa yang muncul adalah komponen harmonisa frekuensi tinggi. Sumber harmonisa frekuensi tinggi tersebut adalah akibat frekuensi modulasi PWM pada rentang $2 \mathrm{~Hz}$ s/d 2 $\mathrm{kHz}$ dan transien dari saklar IGBT saat proses pensaklaran dengan rentang frekuensi antara ratusan $\mathrm{kHz}$ s/d ratusan $\mathrm{MHz}$ (Patel, 2017; Sebaaly et al., 2017; Wang et al., 2011).

Akibat adanya komponen harmonisa frekuensi tinggi tersebut maka digunakan $L P F$ pada PLTS Tomia. LPF yang digunakan merupakan tipe filter pasif terdiri dari elemen resistif, induktif, dan kapasitif. Pada saat survei di lapangan, hanya diketahui nilai kapasitansi dari LPF sedangkan nilai induktansi dan resistansi LPF tidak tersedia. Adapun foto nameplate komponen kapasitor dari LPF yang digunakan pada PLTS Tomia diberikan pada Gambar 4. Berdasarkan Gambar 4., diketahui bahwa nilai kapasitansi tiap fasa adalah $80 \mu \mathrm{C}$ dan kapasitor tersebut disusun secara delta.

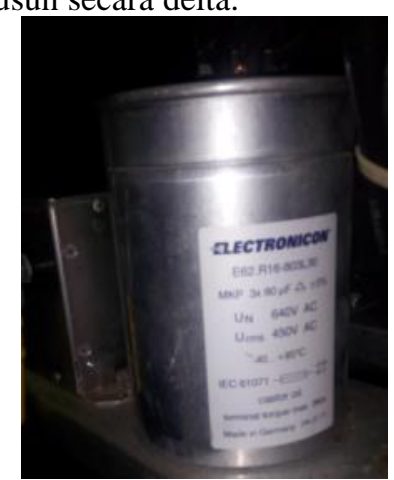

Gambar 4. Elemen kapasitor pada LPF

Adapun trafo untuk GTI yang digunakan pada PLTS Tomia merupakan trafo dengan konfigurasi Dyn11. Trafo GTI yang digunakan memiliki kapasitas $100 \mathrm{kVA}$ dengan nilai impedansi (\%Z) sebesar 3,07\%, dimana rasio tegangan primer dan tegangan sekunder adalah 0,3/0,4 kV. Penggunaan trafo dengan belitan delta pada sisi primer dan belitan Y pada sisi sekunder ditujukan untuk menghilangkan komponen harmonisa orde tiga dan kelipatannya (triplen harmonics). Adapun foto nameplate dari trafo GTI yang digunakan pada PLTS Tomia diberikan pada Gambar 5.

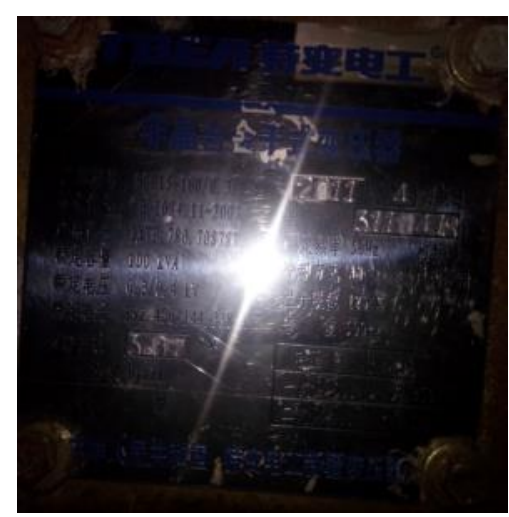

Gambar 5. Trafo GTI PLTS Tomia

Penggunaan $L P F$ dan trafo Dyn11 secara bersamaan akan menyebabkan nilai harmonisa yang lebih rendah dibandingkan output inverter tanpa kedua komponen tersebut. Berdasarkan referensi (SPLN D5.004-1), diketahui bahwa batasan harmonisa total untuk tegangan dan arus berturutturut adalah $5 \%$ untuk total harmonic distortion (THD) tegangan dan $8 \%$ untuk total demand distortion (TDD) arus. Oleh karena itu, $L P F$ dan trafo GTI Dyn11 yang digunakan harus menjamin nilai THD tegangan dan TDD arus tidak melebihi batasan tersebut.

\subsection{Investigasi Penyebab Gangguan}

Berdasarkan hasil observasi di lapangan, didapatkan indikasi munculnya suara dengungan pada trafo GTI PLTS Tomia. Untuk mengetahui lebih lanjut permasalahan pada GTI eksisting maka dilakukan pengukuran pada nilai arus dan tegangan pada sisi primer trafo GTI. Pengukuran pada sisi primer trafo GTI dimaksudkan untuk mengetahui bentuk gelombang tegangan dan arus output dari GTI setelah ditapis oleh $L P F$. Pengukuran kualitas daya pada sisi primer trafo GTI dilakukan selama 2 menit. Durasi pengukuran ini cukup singkat karena PLTS Tomia seketika padam setelah dicoba untuk sinkronisasi dengan grid.

Bentuk gelombang tegangan dan arus hasil pengukuran pada sisi primer trafo GTI berturut-turut diberikan pada Gambar 6. dan Gambar 7. Gambar 6. dan Gambar 7. tidak menunjukkan hasil keseluruhan rekaman dari gelombang tegangan dan arus, melainkan hanya merupakan sampling gelombang pada bagian yang sudah tidak mengalami transien dan memiliki magnitudo terbesar. Gambar 6. dan Gambar 7. kemudian dikaji untuk mengetahui karakteristik tegangan dan arus pada sisi primer trafo GTI. 


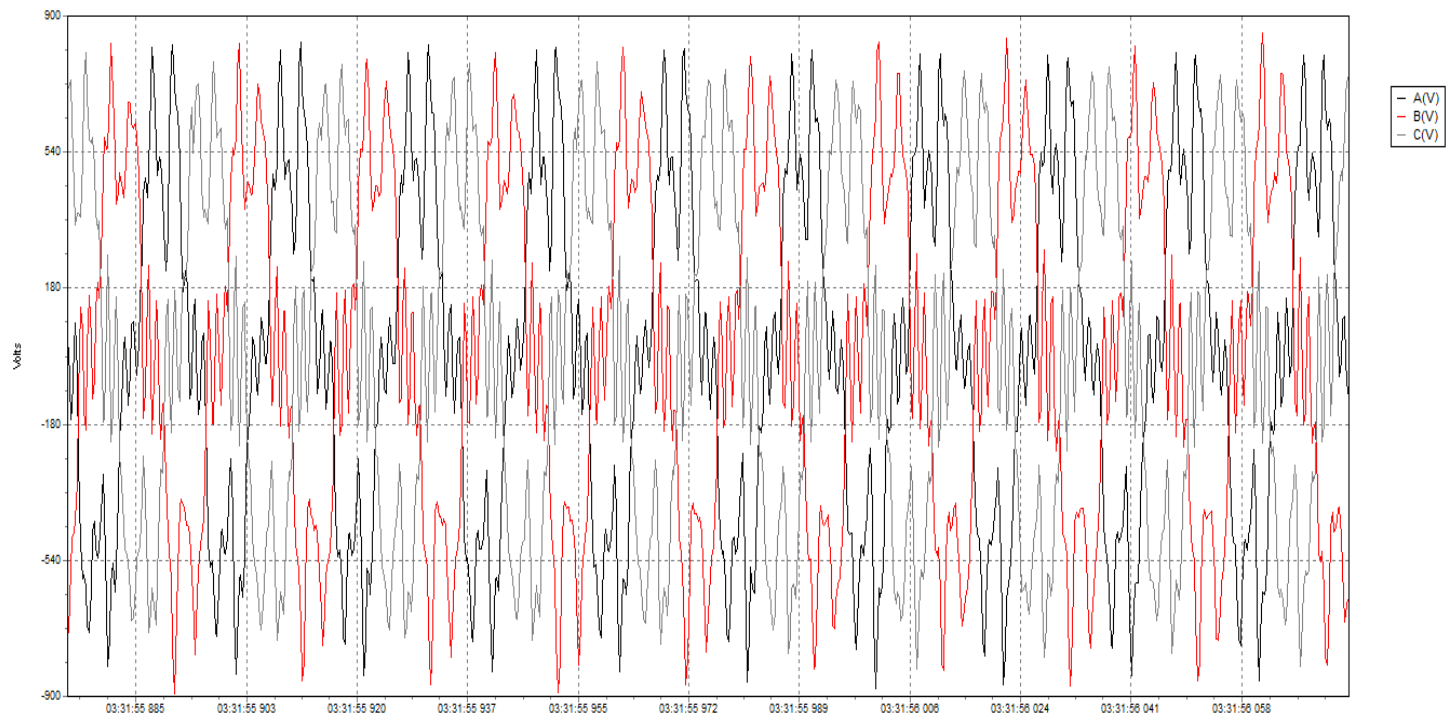

Gambar 6. Hasil pengukuran tegangan pada trafo GTI PLTS Tomia

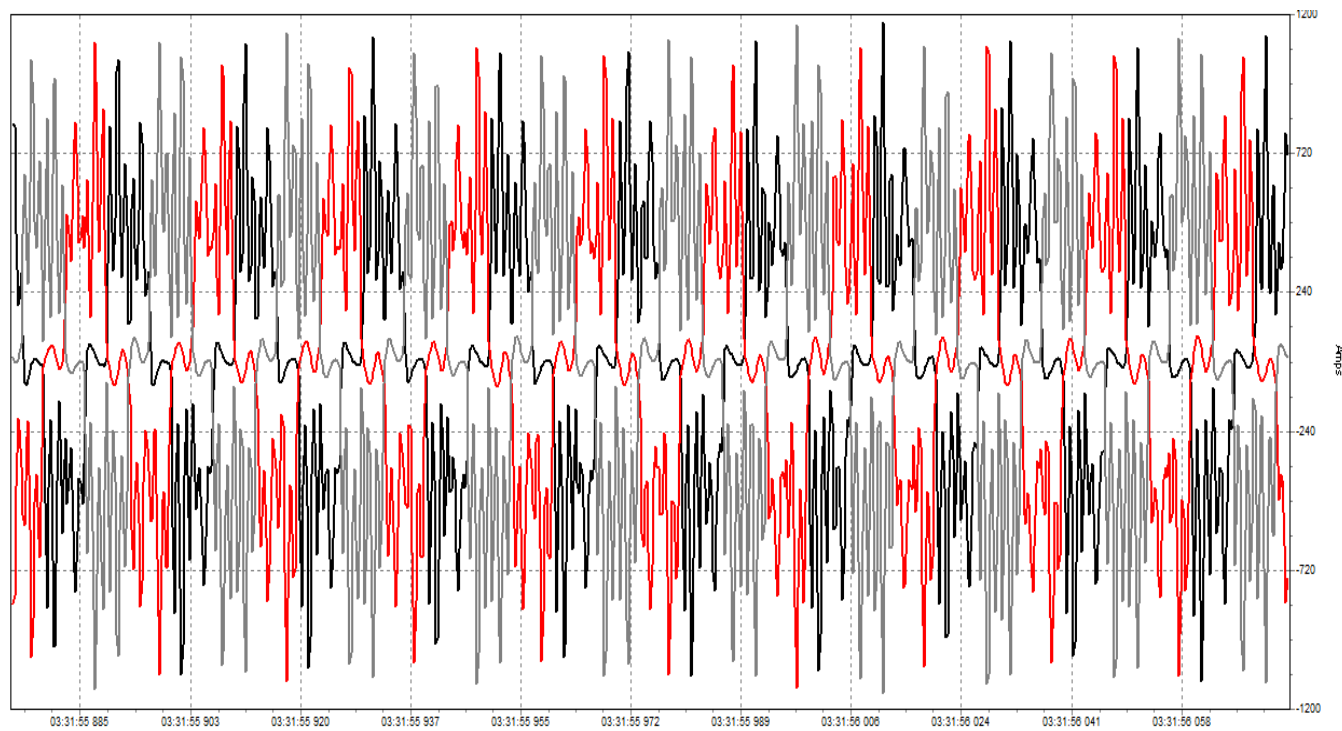

Gambar 7. Hasil pengukuran arus pada trafo GTI PLTS Tomia

Berdasarkan Gambar 6. dan Gambar 7., diketahui bahwa gelombang tegangan dan arus yang masuk pada trafo GTI bukan merupakan gelombang sinusoidal murni. Hal ini diduga disebabkan oleh adanya permasalahan pada kontroler switching IGBT. Permasalahan pada kontroler switching IGBT ini dapat berupa perbedaan nilai frekuensi, amplitudo, dan fasa dari tegangan sinyal referensi maupun sinyal carrier. Hal ini akan menyebabkan munculnya sinyal PWM yang tidak sempurna dan tidak sesuai dengan nilai LPF sehingga nilai tegangan yang dihasilkan tidak berbentuk sinusoidal dan memiliki komponen harmonisa.

Untuk memvalidasi penyebab permasalahan yang terjadi pada GTI, maka dilakukan simulasi menggunakan perangkat simulasi transien. Dalam proses simulasi, model inverter disesuaikan sedekat mungkin dengan data riil yang ada di lapangan (sebagai model awal) kemudian dilakukan variasi nilai pada $L P F$ (komponen resistif dan induktif), komponen trafo GTI, dan mode pensaklaran dari IGBT pada blok GTI (modulasi frekuensi dan modulasi magnitudo). Model trafo GTI yang digunakan dalam simulasi menggunakan model trafo dengan komponen kapasitansi (stray capacitance) selain komponen induktif dan resistif. Terdapat empat tipe kapasitansi, yaitu: kapasitansi belitan ke tanah, kapasitansi belitan ke belitan, dan kapasitansi antar lilitan, dan kapasitansi dari bagian akhir dari belitan salah satu fasa ke bagian akhir dari belitan fasa lainnya (Akbari et al., 2020; Munir et al., 2016; Munir et al., 2017; Mailhot \& Munar, 1995). Adapun hasil simulasi diberikan pada Gambar 8 dan Gambar 9. 


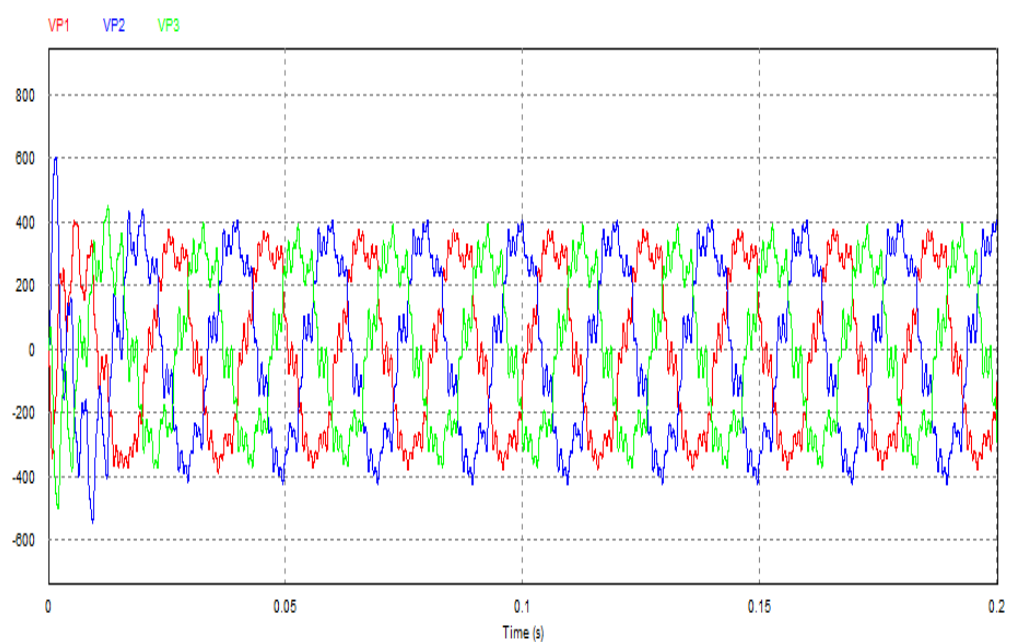

Gambar 8. Tegangan hasil simulasi pada trafo GTI PLTS Tomia

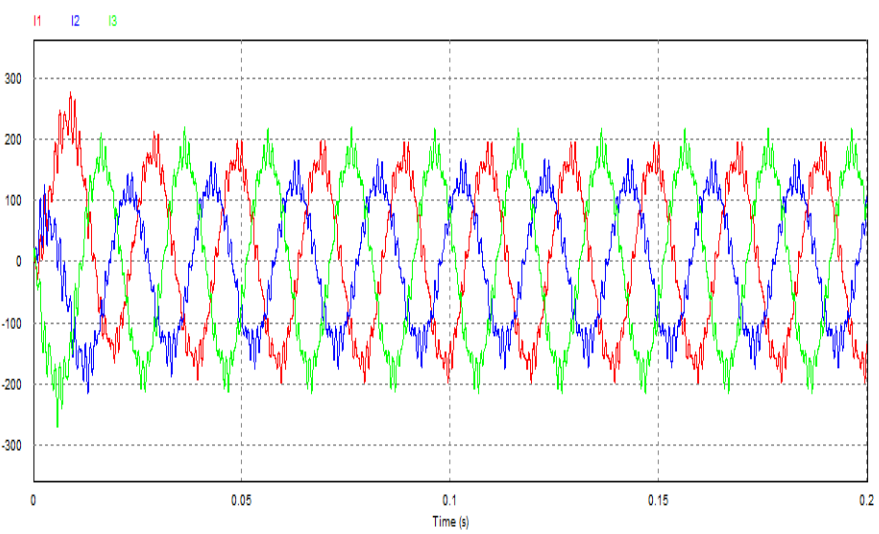

Gambar 9. Arus hasil simulasi pada trafo GTI PLTS Tomia

Dari hasil simulasi tersebut diketahui bahwa terdapat nilai arus urutan nol yang bersirkulasi dalam belitan delta trafo dengan nilai sebesar -56 A hingga 65 A. Arus urutan nol ini diindikasikan sebagai penyebab dengungan pada trafo GTI eksisting. Nilai arus urutan nol tersebut terjadi ketika dilakukan simulasi penyaklaran IGBT dengan nilai frekuensi dan amplitudo yang tidak sesuai dengan spesifikasi $L P F$ yang terdapat pada GTI eksisiting. Hal ini menunjukkan bahwa terjadi permasalahan kontrol pensaklaran MPPT pada GTI eksisting.
Selain permasalahan yang terdapat pada GTI dan combiner box, PLTS Tomia juga mengalami permasalahan pada komponen baterai. Permasalahan pada komponen baterai berupa cairan baterai yang habis, kutub baterai yang berkarat, serta rusaknya inverter baterai (bidirectional inverter). Dengan demikian, maka dibentuk diagram root cause problem solving (RCPS) untuk proses revitalisasi PLTS Tomia seperti yang diberikan pada Gambar 10. 


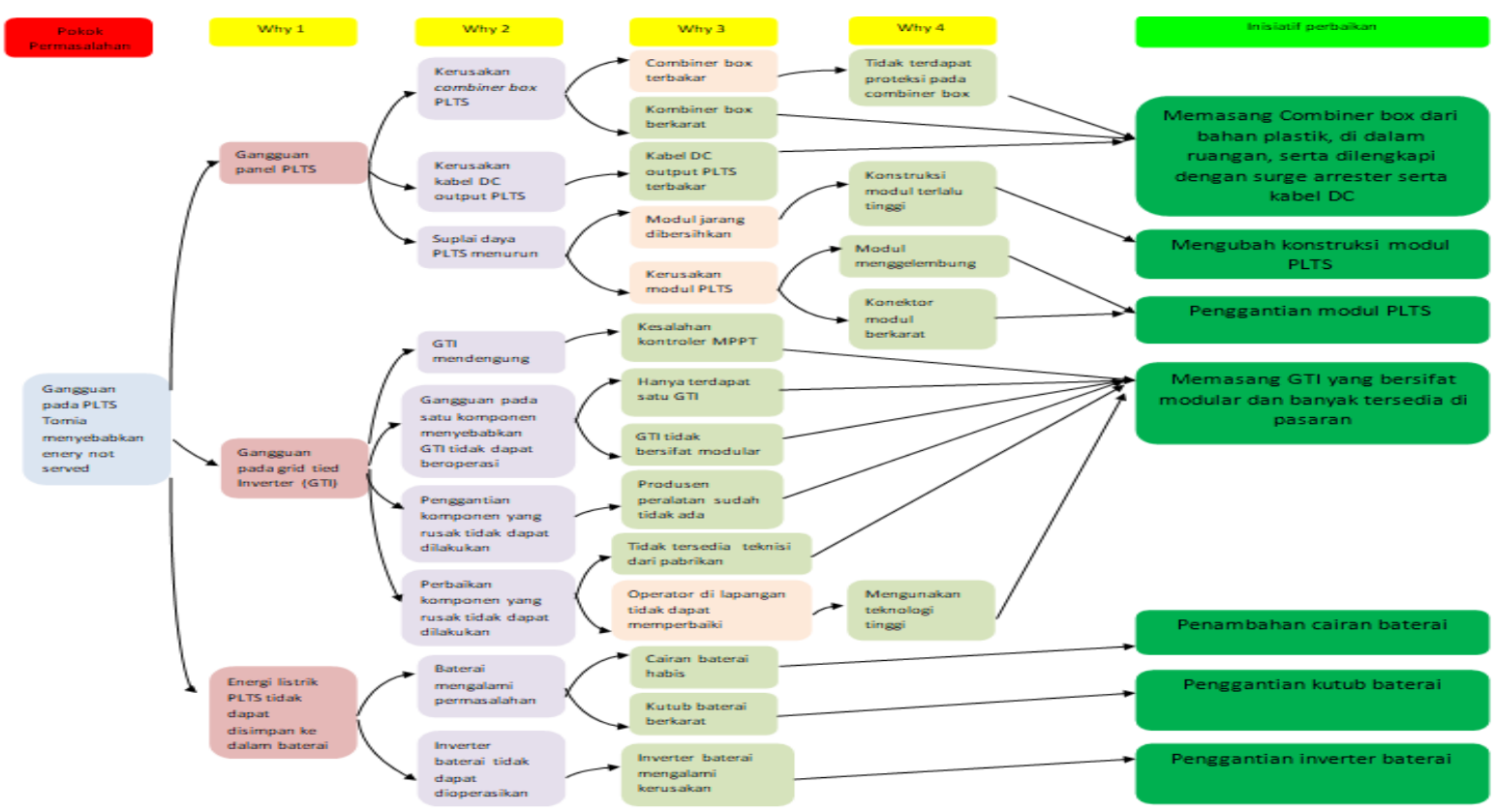

Gambar 10. Diagram RCPS dalam revitalisasi PLTS Tomia

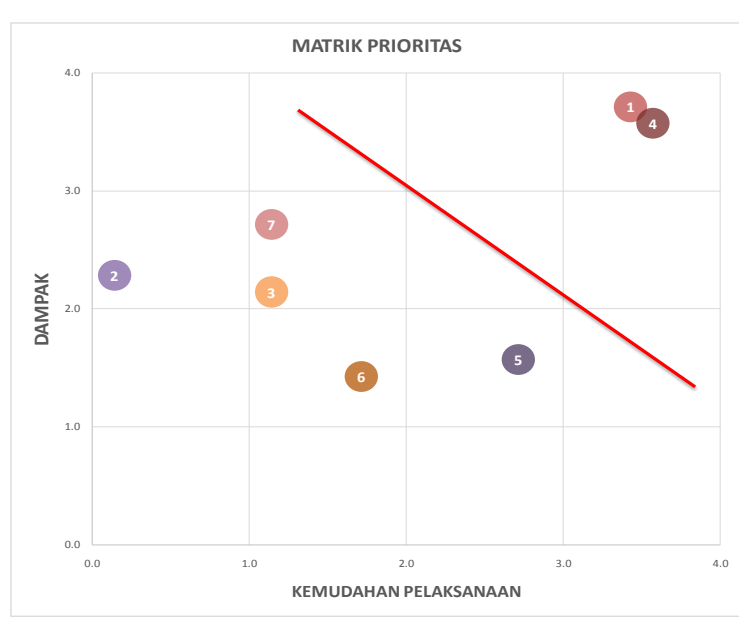

Gambar 11. Matriks prioritas dalam revitalisasi PLTS Tomia

Matriks prioritas ditentukan berdasarkan potensi manfaat (dampak) hasil perbaikan serta kemudahan dilaksanakannya perbaikan (Gambar 11.). Semakin tinggi dampak dan semakin mudah dilakukannya inisiatif perbaikan akan meningkatkan prioritas inisiatif perbaikan tersebut untuk ditindaklanjuti. Berdasarkan hasil matriks prioritas maka didapatkan dua inisiatif perbaikan yang akan ditindaklanjuti yaitu inisiatif perbaikan nomor 1 dan nomor 4 yang masing-masing merupakan "Memasang combiner box dari bahan plastik, di dalam ruangan, serta dilengkapi dengan surge arrester serta kabel DC" dan "Memasang GTI yang bersifat modular yang banyak tersedia di pasaran".

\section{HASIL DAN PEMBAHASAN}

3.1. Desain Ulang Konfigurasi PLTS Tomia

Revitalisasi PLTS Tomia dilakukan dengan menggunakan konsep GTI modular. Keluaran panel surya yang awalnya hanya terdiri dari satu array diubah menjadi empat array. Keempat array tersebut kemudian dihubungkan dengan masing-masing GTI melalui dua combiner box. Array 1 dihubungkan dengan GTI merk A, array 2 dihubungkan dengan GTI merk B, array 3 dihubungkan dengan GTI merk C, dan array 4 dihubungkan dengan GTI merk D. Pemilihan empat GTI dengan merk berbeda bertujuan untuk mengetahui kinerja dari keempat merk GTI yang terdapat di pasaran. Skematik sistem PLTS Tomia setelah dilakukan revitalisasi diberikan pada Gambar 12.

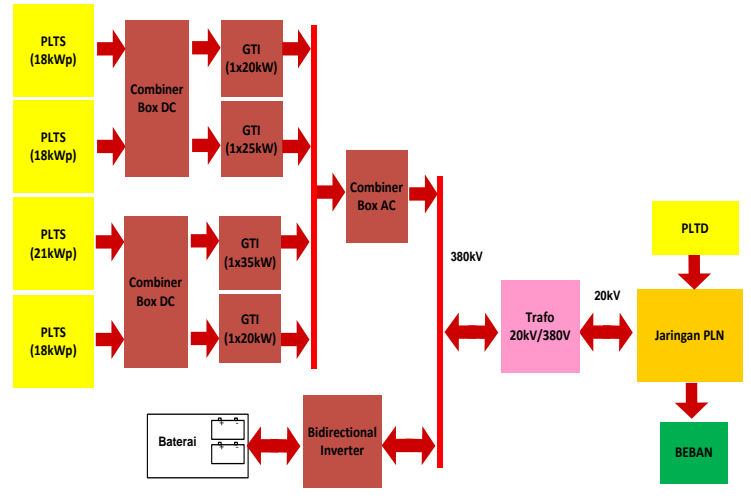

Gambar 12. Diagram hasil revitalisasi PLTS Tomia

Awalnya PLTS Tomia menggunakan hanya satu GTI dengan kapasitas $75 \mathrm{kWp}$ sehingga ketika komponen kontrol MPPT pada GTI tersebut rusak maka keseluruhan sistem PLTS tidak dapat digunakan terlebih lagi pabrikan penyedia GTI eksisting sudah tidak beroperasi. Dengan 
menggunakan konsep modular pada GTI diharapkan permasalahan yang pernah terjadi sebelumnya tidak kembali terulang. Jika terjadi kerusakan pada satu GTI, maka daya dari array yang mengalami permasalahan GTI dapat dipindahkan ke tiga GTI lainnya sehingga PLTS Tomia tetap dapat beroperasi penuh. Selain itu, dengan GTI modular, jika terjadi kerusakan, perbaikan tidak bergantung hanya pada satu merk melainkan dapat menggunakan berbagai macam merk yang mudah didapatkan di pasaran.

Uji fungsi peralatan dilakukan untuk memastikan bahwa peralatan yang akan dipasang dapat digunakan dengan baik untuk revitalisasi PLTS Tomia. Diharapkan dengan dilakukan tindakan ini, pekerjaan di lokasi PLTS dapat segera dilaksanakan tanpa mengalami kendala peralatan. Proses uji fungsi yang dilakukan di laboratorium diberikan pada Gambar 13.
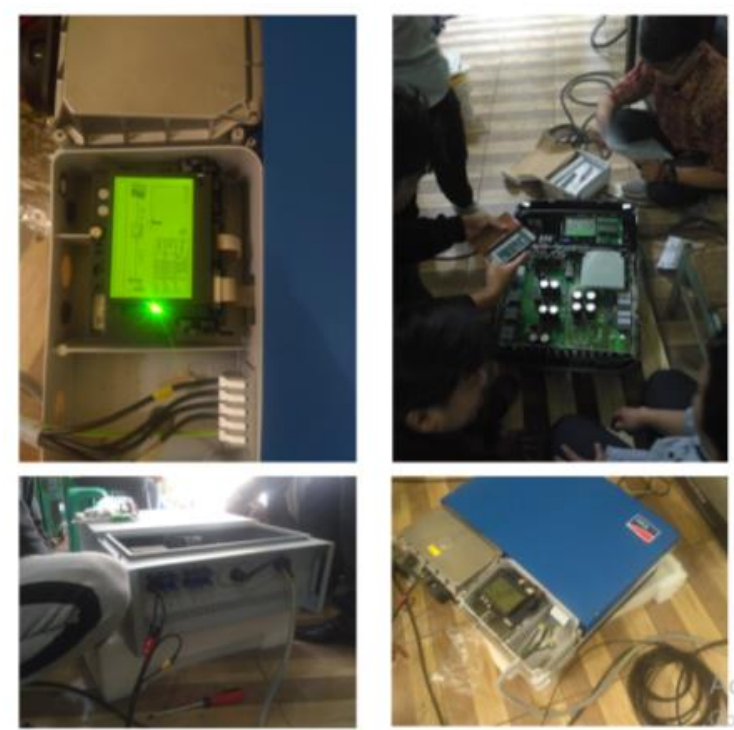

Gambar 13. Uji fungsi GTI

GTI eksisting awalnya berbentuk kubikel dengan ukuran yang cukup besar ( $2 \mathrm{~m}$ x 0,6 m x 1,2 m) dan berada di tengah ruangan, sedangkan pada proses revitalisasi, GTI dipasang pada dinding (ukuran rata-rata dari seluruh GTI adalah $0,3 \mathrm{~m} \mathrm{x} \mathrm{0,6}$ $\mathrm{m} \times 0,5 \mathrm{~m})$ agar dapat mengoptimalkan ruangan sehingga terdapat ruang kosong yang dapat digunakan oleh operator untuk memantau kinerja GTI. Proses pengerjaan hingga kondisi final terpasangnya GTI diberikan pada Gambar 14.

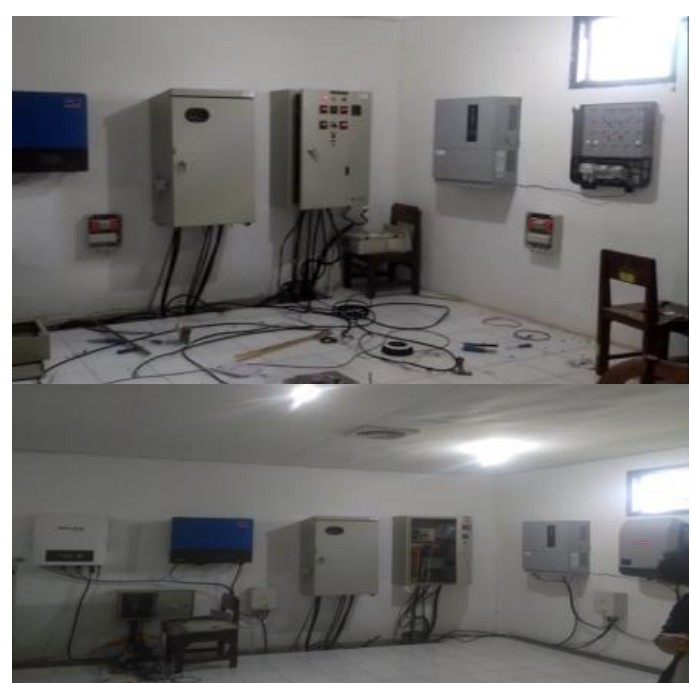

Gambar 14. Kondisi PLTS Tomia setelah revitalisasi

\subsection{Pengukuran Harmonisa dan Potensi Penghematan}

Setelah seluruh peralatan selesai diinstalasi, maka selanjutnya dilakukan pengukuran harmonisa arus dan tegangan serta daya output yang dihasilkan oleh masing-masing GTI. Hasil pengukuran harmonisa, daya output GTI, dan spesifikasi dari masing-masing GTI ini diberikan pada Tabel 1. Sedangkan, hasil pengukuran simultan untuk daya dan harmonisa pada keempat GTI diberikan pada Gambar 15. dan Gambar 16.

Tabel 1. menunjukkan bahwa keempat GTI tersebut memiliki THD tegangan maksimum sebesar 2,5\%. Sedangkan nilai THD arus yang ditampilkan pada Tabel 1 adalah nilai THD maksimum selama proses pengukuran. GTI merk C memiliki nilai THD arus yang paling rendah, yaitu sebesar $6 \%$ sedangkan GTI merk A memiliki harmonisa arus tertinggi, yaitu sebesar $16 \%$. Namun ketika keseluruhan GTI tersebut diukur secara bersama-sama pada sisi primer trafo step up 20kV/380V, maka nilai THD tegangan dan arus maksimum yang diperoleh berturut-turut adalah lebih rendah dari 3\% dan $8 \%$. Berdasarkan (SPLN D5.004-1) dapat diketahui bahwa nilai harmonisa maksimum yang boleh dihasilkan oleh peralatan adalah sebesar $5 \%$ untuk harmonisa tegangan dan $8 \%$ untuk harmonisa arus. Dengan demikian, konfigurasi PLTS hasil revitalisasi ini masih memenuhi standar batasan nilai harmonisa sehingga dapat dioperasikan secara kontinu. 


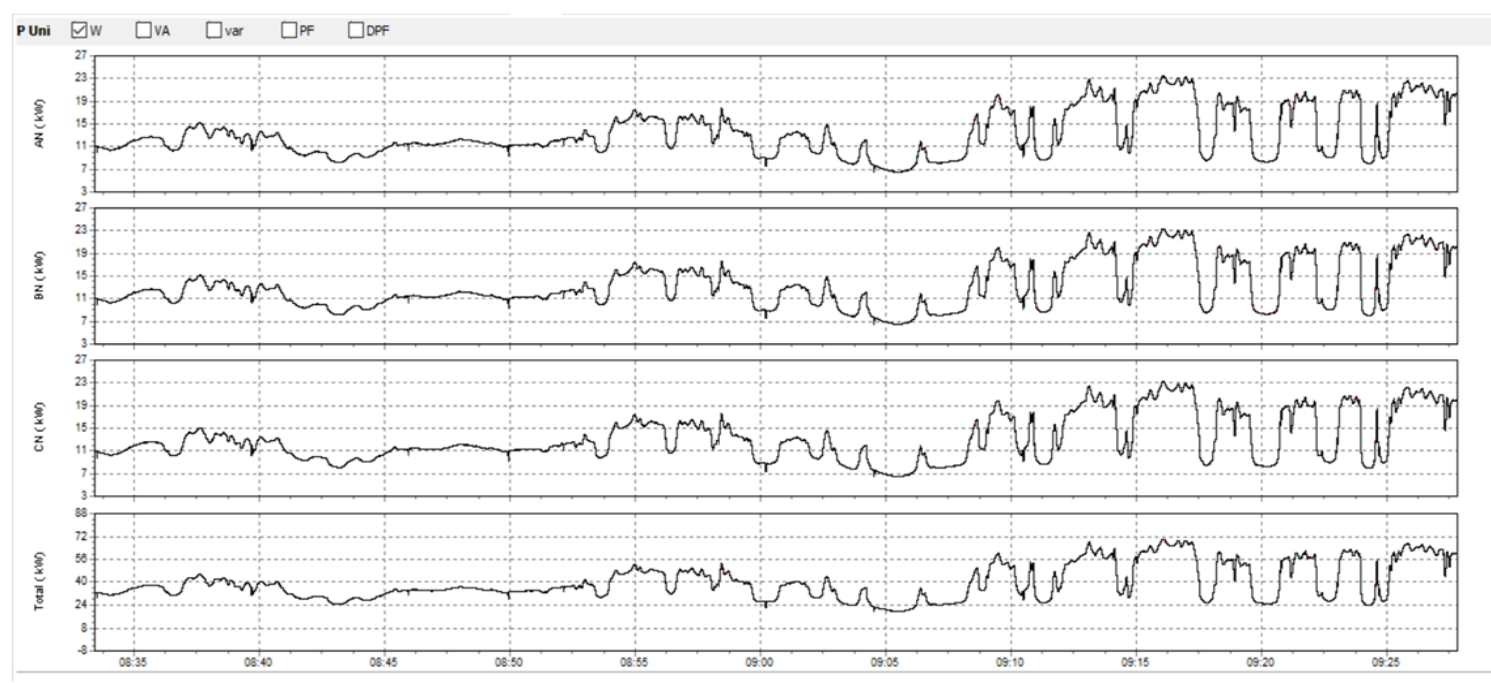

Gambar 15. Hasil pengukuran daya secara simultan untuk keseluruhan GTI

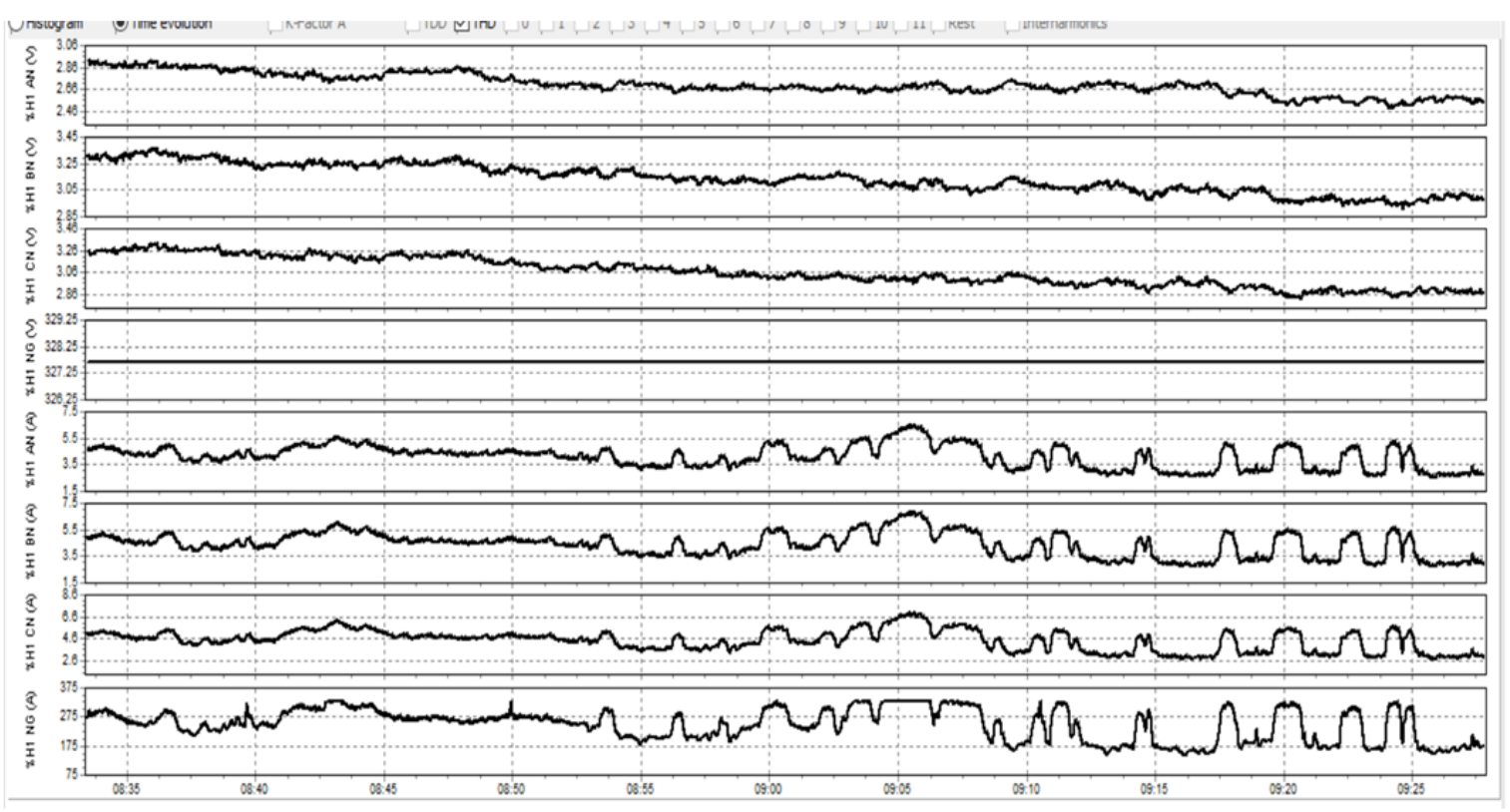

Gambar 16. Hasil pengukuran harmonisa tegangan dan arus secara simultan untuk keseluruhan GTI

Tabel 1

Perbandingan karakteristik GTI yang dipasang pada PLTS Tomia

\begin{tabular}{rlrrrrrr}
\hline No. & Merk & \multicolumn{1}{c}{$\begin{array}{c}\text { THD } \\
\text { Arus }\end{array}$} & $\begin{array}{c}\text { THD } \\
\text { Tegangan }\end{array}$ & $\begin{array}{c}\text { Daya } \\
\text { Terukur } \\
(\mathrm{kW})\end{array}$ & $\begin{array}{c}\text { Kapasitas } \\
\text { Terpasang } \\
(\mathrm{kW})\end{array}$ & $\begin{array}{c}\text { Asal } \\
\text { Pabrikan }\end{array}$ & Garansi \\
\hline 1 & A & $16 \%$ & $2,50 \%$ & 17 & 20 & Asia & 5 tahun \\
2 & B & $14 \%$ & $2,50 \%$ & 17 & 25 & Eropa & 5 tahun \\
3 & C & $6 \%$ & $2,50 \%$ & 17 & 35 & Asia & 5 tahun \\
4 & D & $8 \%$ & $2,50 \%$ & 18 & 20 & Eropa & 5 tahun \\
\hline
\end{tabular}

Total kapasitas GTI yang terpasang di PLTS Tomia adalah sebesar $100 \mathrm{~kW}$, yaitu lebih besar dari kapasitas PLTS yang terpasang. Hal tersebut dilakukan agar ketika terjadi kerusakan pada salah satu GTI, daya dari PLTS yang mengalami kerusakan GTI tersebut dapat dipindahkan ke tiga GTI lainnya. 
Dengan demikian, jika terjadi gangguan pada salah satu GTI maka keseluruhan daya dari PLTS tetap dapat disuplai ke jaringan.
Perhitungan besarnya potensi energi yang dapat disuplai dari PLTS Tomia serta potensi penghematan setelah dilakukan revitalisasi diberikan pada Tabel 2.

Tabel 2

Potensi penghematan hasil revitalisasi PLTS Tomia

\begin{tabular}{lcc}
\hline \multicolumn{1}{c}{ Parameter per tahun } & Tanpa Beroperasinya PLTS & Dengan PLTS Operasi \\
\hline Produksi PLTS $(\mathrm{kWh}){ }^{*}{ }^{*}$ pendekatan nilai & & 122.103 \\
iradiasi tahunan mengacu pada data Global Solar & - & 3.750 .651 \\
Atlas (Anonim, 2021) & 3.872 .754 & 0,280 \\
Produksi PLTD (kWh) & 0,280 & 1.050 .182 \\
SFC (liter/kWh) & 1.084 .371 & 11 \\
Konsumsi bahan bakar (liter) & 11 & 11.552 .006 .097 \\
Harga bahan bakar (Rp/liter) & 11.928 .083 .200 & 2.983 \\
Biaya bahan bakar (Rp) & 3.080 & 376.077 .103 \\
BPP (Rp/kWh) & & \\
\hline Penghematan selama satu tahun (Rupiah) & & \\
\hline
\end{tabular}

Berdasarkan hasil perhitungan tersebut dapat diketahui bahwa PLTS Tomia setelah revitalisasi berpotensi menghasilkan energi listrik sebesar $122.103 \mathrm{kWh}$ per tahun sehingga akan diperoleh potensi penghematan sebesar Rp. 376.077.103 per tahun. Nilai penghematan ini diperoleh dari selisih antara biaya bahan bakar ketika dioperasikan dan tidak dioperasikannya PLTS Tomia. Selain itu, didapatkan potensi penurunan biaya pokok produksi (BPP) listrik dari Rp. 3.080,- menjadi Rp. 2.983,ketika PLTS Tomia dapat beroperasi kembali. Jika dibandingkan dengan biaya yang digunakan untuk proses revitalisasi yaitu sebesar Rp. 300.000.000, biaya dalam proses perbaikan ini akan kembali dalam waktu satu tahun.

\section{PENUTUP}

Proses revitalisasi PLTS Tomia telah dilaksanakan dengan melalui tahapan review desain eksisting PLTS Tomia, investigasi penyebab gangguan, inisiatif perbaikan, dan desain ulang PLTS Tomia. Dengan menggunakan konsep GTI modular, PLTS Tomia hasil revitalisasi dapat digunakan dan menghasilkan kualitas daya yang masih memenuhi nilai standar. Selain itu, PLTS Tomia hasil revitalisasi berpotensi menurunkan nilai BPP Listrik dari Rp. 3.080/kWh menjadi Rp. 2.983/kWh.

\section{DAFTAR PUSTAKA}

Akbari, M., Member, S., Rezaei-zare, A., Member, S., Ali, M., Cheema, M., \& Kalicki, T. (2020). Air Gap Inductance Calculation for Transformer Transient Model. 3(c), 5-7. https://doi.org/10.1109/TEC.2020.3009818

Bae, S., Member, S., \& Kwasinski, A. (2012). Dynamic Modeling and Operation Strategy for a Microgrid With Wind and Photovoltaic Resources. 1-9.

Che, L., Member, S., Shahidehpour, M., \&
Alabdulwahab, A. (2015). Hierarchical Coordination of a Community Microgrid With $A C$ and DC Microgrids. 1-10.

Liu, T.H., Mubarok, M. S., Ridwan, M. Suwarno. (2019). Design and Implementation of a SpeedLoop-Periodic-Controller-Based FaultTolerant SPMSM Drive System.

Dong, X. I. N., Member, S., Li, X., \& Cheng, S. (2020). Energy Management Optimization of Microgrid Cluster Based on Multi-AgentSystem and Hierarchical Stackelberg Game Theory. 8, 206183-206197.

H, B. B. S. D. A., Munir, B. S., Habibie, A. S., \& Alam, A. S. (2016). kV 500 MVA in Parallel Operation. 3(1), 1-5.

H, B. B. S. D. A., Munir, B. S., Habibie, A. S., Inspection, A. V., \& Bank, P. S. (2017). 500MVA Inter Bus Transformer. 7th International Annual Engineering Seminar (InAES), 7-11. Yogyakarta.

Jiang, Z., Gao, L., Dougal, R. A., \& Member, S. (2007). Adaptive Control Strategy for Active Power Sharing in Hybrid Fuel Cell / Battery Power Sources. 22(2), 507-515.

Jos, P., Silveira, C., Member, S., \& Filho, E. R. (2020). Power Management Strategy Based on Virtual Inertia for DC Microgrids. IEEE TRANSACTIONS ON POWER ELECTRONICS, in press. https://doi.org/10.1109/TPEL.2020.2986283

Mailhot, T. N. M., \& Munar, A. (1995). Zero Phase Sequence Impedance and Tank Heating Model for Three Phase Three Leg Core Type Power Transformers Coupling Magnetic Field and Electric Circuit Equations in a Finite Element Software. 31(3), 2068-2071.

Mckeon, B. B., Furukawa, J., \& Fenstermacher, S. (2014). Advanced Lead - Acid Batteries and the Development of Grid-Scale Energy Storage Systems. Proceedings of the IEEE, 102(6), 
951-963.

https://doi.org/10.1109/JPROC.2014.2316823

Member, S., Luna, A. C., Member, S., Vasquez, J. C., \& Fellow, J. M. G. (2016). Centralized Control Architecture for Coordination of Distributed Renewable Generation and Energy Storage in Islanded AC Microgrids. 8993(c). https://doi.org/10.1109/TPEL.2016.2606653

Patarroyo-montenegro, J. F., Andrade, F., Guerrero, J. M., Vasquez, J. C., \& Member, S. (2020). Transactions on Power Electronics A Linear Quadratic Regulator with Optimal Reference Tracking for Three-Phase Inverter-based Islanded Microgrids. https://doi.org/10.1109/TPEL.2020.3036594

Patel, P. (2017). PLL less Strategy for Grid Tied Inverter with Different Load Conditions. 1-4.

Sebaaly, F., Student, G., Vahedi, H., \& Student, G. (2017). Novel Current Controller Based on MPC with Fixed Switching Frequency Operation for a Grid-Tied Inverter. 0046(c). https://doi.org/10.1109/TIE.2017.2784400

Serban, I., Teodorescu, R., \& Marinescu, C. (2013). Energy storage systems impact on the shortterm frequency stability of distributed autonomous microgrids, an analysis using aggregate models. (September). https://doi.org/10.1049/iet-rpg.2011.0283

SPLN D5.004-1: 2012, Power Quality (Regulasi Harmonisa, Flicker dan Ketidakseimbangan Tegangan).

Wang, Y., Gao, Q., \& Cai, X. (2011). Mixed PWM for Dead-Time Elimination and Compensation in a Grid-Tied Inverter. 58(10), 4797-4803.

Xia, K., He, S., Tan, Y., Jiang, Q., Xu, J., \& Yu, W. (2019). Wavelet packet and support vector machine analysis of series DC ARC fault detection in photovoltaic system. IEEJ Transactions on Electrical and Electronic Engineering, 14(2), 192-200. https://doi.org/10.1002/tee.22797

Zhao, Z., Member, S., Yang, P., \& Guerrero, J. M. (2015). Multiple-Time-Scales Hierarchical Frequency Stability Control Strategy of Medium-Voltage Isolated Microgrid. 8993(c), $1-18$. https://doi.org/10.1109/TPEL.2015.2496869

Anonim, https://globalsolaratlas.info/map?c=$\underline{5.921778,123.078003,8 \& \mathrm{~s}=-}$ $\underline{5.742906,123.936768 \& \mathrm{~m}=\text { site }}$, Dikutip pada tanggal 14 April 2021, pukul 15.00 WIB 